\title{
EFFICACY TESTING OF A 35 YEAR OLD COMMERCIALLY PRODUCED YERSINIA RUCKERI BACTERIN FOR THE CONTROL OF ENTERIC REDMOUTH (ERM) DISEASE
}

\author{
Scott E LaPatra ${ }^{1 *}$, Tim J Welch ${ }^{2}$ \\ ${ }^{1}$ Clear Springs Foods, Inc., Research Division, Buhl, Idaho USA. \\ ${ }^{2}$ National Center for Cool and Cold Water Aquaculture, Kearneysville, West Virginia, USA.
}

\begin{abstract}
In 1976 the United States Department of Agriculture, Veterinary Services, granted the first veterinary product license for a biologic to be administered to fish. That license was issued for Enteric Redmouth Bacterin (Yerisina ruckeri) to the first commercial fish vaccine company, Wildlife Vaccines. This bacterin is widely used to control enteric redmouth disease (ERM). Licensed Y. ruckeri bacterins are administered to salmonid fish one gram in size and larger by immersion, automated immersion, showerspray and oral methods. At that time the most extensive use of $Y$. ruckeri bacterins were by the commercial rainbow trout industry located in southern Idaho. A $2 \frac{1}{2} 2$ year program designed to evaluate the efficacy of immersion applied Y. ruckeri bacterins was initiated in 1978. Approximately 22 million fish were vaccinated under this program. Results obtained from this large scale field study of vaccinated and non-vaccinated fish demonstrated that mortality attributable to ERM disease as well as medicated feed requirements to treat this disease were significantly reduced. Feed conversion rates improved in vaccinated fish and as a direct result the time period required for rearing these fish was reduced.

Recently, a bottle of ERM bacterin that was well over 30 years old and labeled by Wildlife Vaccines with a serial number of 236 and an expiration date of October 18, 1982 was discovered in a storage closet at room temperature at the Clear Springs Foods Research Division. In-vivo testing was initiated in juvenile rainbow trout (mean weight, $6 \mathrm{~g}$ ) using the old Wildlife Vaccine product and an ERM vaccine produced in-house at Clear Springs. The vaccines were delivered to separate groups of fish by either immersion or injection and waterborne challenged with two doses of a virulent biotype 1 strain of $Y$. ruckeri 400 degree days post-vaccination.
\end{abstract}

\section{KEYWORDS}

Yersinia ruckeri, trout, ERM, vaccine

Corresponding author. Tel.: +1 208-543-3465; Fax: +1 208-543-4146

E-mail address: scott.lapatra@ clearsprings.com 